\title{
Epistemological Proposal on the Concept of Hybridity for Libraries
}

\author{
Rafaela Carolina DA SILVA and Rosângela Formentini CALDAS \\ University of Sao Paulo/PostGraduation Program of Information Science, Marilia, Brazil \\ Correspondence should be addressed to: Rafaela Carolina DA SILVA; rafaela.c.silva@unesp.br \\ Received date: 26 March 2020; Accepted date: 21 July 2020; published date: 14 September 2020 \\ Copyright (C) 2020. Rafaela Carolina DA SILVA and Rosângela Formentini CALDAS. Distributed \\ under Creative Commons Attribution 4.0 International CC-BY 4.0
}

\begin{abstract}
The Information Science field has discussed different shared specifications of a conceptualization which comprises the diversity of support, processes, resources and people by which the library needs to adapt. The question here is about the conceptual identification of the terminology "hybrid libraries; The aim is to contribute to the literature in the Information Science field by proposing a concept of hybrid libraries which comprises the social sphere, in terms of the developments existing in the society, in libraries. The study is theoretical and aims at discussing and improving theoretical and conceptual foundations. It is a qualitative and bibliographical research. The method of Discourse Analysis is used to analyze the concepts of hybrid libraries developed by authors who study the theme. It is noticed that in the hybrid library environment, there is a greater flexibility in products and services offered, since it originates from an organizational structure which proposes multiplicity of languages in the institution practices. The epistemological discussion in the construction of a concept of hybrid libraries needs to take into account the impact of the use of technologies on the provision of services that promote the social inclusion of communities in each hybrid environment, considering their cultures, values and principles.
\end{abstract}

Keywords: Hybrid libraries. Concept of hybrid libraries. Epistemological proposal

\section{Introduction}

Since this theme is still controversial in the Information Science field, the discussion about the concept of hybridity in libraries for the social development is essential so that studies in the field can evolve. Therefore, the research herein, currently at the Doctorate level, represents the development of initial

Cite this Article as: Rafaela Carolina DA SILVA and Rosângela Formentini CALDAS (2020), "Epistemological proposal on the concept of hybridity for libraries", Journal of Administrative Sciences and Technology, Vol. 2020 (2020), Article ID 558394, DOI: 10.5171/2020.558394 
discussions regarding a field study initiated in the Master's Degree, which sought to analyze, through a field research, the national (Brazilian) hybrid libraries and the international ones (English and Scottish), and their relationship with the development of communities. The research resulted in an exchange program to Europe, revealing that in countries like England and Scotland, the cultural sphere shows itself as a hybrid factor in informational equipment, involving technologies as tools that help in the development of library activities. Hence, the conception of hybrid libraries given by researchers from such territories is: that they are cultural equipment that must integrate technologies in order to help the individual in the community.

Some similarities between libraries in the United Kingdom and Brazil are closely related to the proposal in the sense that the role of these libraries is to promote cultural actions in order to create reading and writing opportunities for all groups of their user population. However, the big difference lies in the fact that the former have a strong theoretical basis in the hybrid literature for the development of their practices, while the later are based on the literature of living libraries (Da Silva, 2017). Therefore, it was noticed that the hybrid concept in libraries, both in Brazil and internationally, is still confusing and contradictory. In the light of the above, some questions could be raised: "What is a hybrid library?", "Why is it misunderstood by the concept of living libraries? "What is the relationship between them?", "What are the social and technological requirements needed?", "What are the aspects involved?", "Where do they come from?", "In what situation?", "In what context?", and "Why do many libraries claim to be hybrid, but in practice they do not act in the cultural sphere of their communities?". Therefore, the problem of this research is related to the divergence of opinions about the concept of hybrid libraries which, while they contribute to the discussions about the theme, they can negatively influence the production of content about the theme, as well as the professional performance in the informational equipment.

The hypothesis is that, when they are not sure about how they should operate in hybrid environments, librarians may manage the institutions, where they work, in a way in which they focus their activities only on the technological aspects of information, failing to emphasize the cultural sphere and the social inclusion of the community in which they operate. To this end, the proposal is to raise discussions involving experts, librarians and institutions that work with the concept of hybrid libraries in order to analyze them and define the basic characteristics for the hybrid concept in libraries. The following question was intended to be answered: "Taking into account the divergences arising from the opinions of researchers, the different cultural spheres involving hybrid libraries, as well as the need for an epistemological contribution to the development of concepts, what are the basic requirements that underlie the hybrid concept in libraries?". Therefore, this study aims at contributing to the Information Science literature, proposing a concept of hybrid libraries which encompasses the social sphere within the scope of existing developments in society, in libraries.

The aim was to discuss not only the involvement of technologies in libraries, which seems to be the common sense of hybridity in this respect, but also the way in which the hybrid library can contribute to the development of communities. More specifically, this research aimed to: collect concepts from authors of the theme of hybridity at national and international levels to understand the different opinions about the theme and propose a

Rafaela Carolina DA SILVA and Rosângela Formentini CALDAS (2020), Journal of Administrative Sciences and Technology, DOI: 10.5171/2020.558394 
consensus on the importance of the social sphere to work on hybridity; substantiate the epistemology of the institutions considered hybrid; highlight the characteristics and rationale which contextualize the hybrid concept beyond technology; analyze the resources (human, technological and social), as well as the relevant services for building a hybrid concept in libraries which can be accepted in the Information Science literature.

In the face of the above, one of the main ways of reporting the importance of contributing to the epistemological discussion about the concept of hybridity for libraries is showing that these environments support diverse users in different cultural circles. Thus, the ultimate aim of this research is for libraries to become spaces for entertainment, communication, social interaction, study and research, that is, to act actively in their cultural spheres.

\section{The Method}

The research is characterized as theoretical and seeks to discuss and improve theoretical and conceptual foundations. Its nature is qualitative and bibliographic because, based on the analysis of concepts given in the literature and by institutions considered hybrid at national and international levels, it sought to retrieve information about the universe of research, examining a particular concept, using instruments of data collection and analysis. The study uses the method of Discourse Analysis to analyze the concepts of hybrid libraries developed by the authors who study the theme.

Unfinished in the data analysis part, the method of Discourse Analysis will support the ways of understanding the discourses in the texts of those researchers who study hybrid libraries in the Information Science field. This method aims to understand why those researchers have acquired such a conception and not the other, thus highlighting the subject-form of the discourse, as well as the discourseinterdiscourse relationship, and encompassing its paraphrase and polysemy, for the construction of an Archeology of Knowledge. For this purpose, the institutions in which the discourse is produced, the historical and social conflicts which define the discourse and the space that each discourse takes within the interdiscourse were designated as forms of analysis. The study intended to develop a discursive analysis of the concept of hybrid libraries at literature, documentation and governance of hybrid libraries and compare between different countries' models through that. Some interviews were also conducted with hybrid librarians. Regarding Foucault 1971, the Discourse Analysis provides the development of an Archeology of Knowledge, because no discourse, or materialized text, is autonomous or enough, but it relies on others. The subject of the new discourse is created to develop an interdiscursive purpose with the previous discourses. Thus, the construction of an Archeology of Knowledge is appropriate for the development of the concept of hybrid libraries, because it provides the evolution of the concept of hybridity in libraries.

Firstly, the Discourse Analysis will be applied in authors' speeches about the concept of hybrid library carried out in the articles founded in the literature review. For this, phrases from articles will be highlights in which the authors conceptualize, with their words, the term hybrid library. This conceptualization will be analyzed from the conceptual construction of the article as a whole. The literature review approached the following databases: Library and 
Information Science Abstracts (LISA), Base de Dados de Periódicos em Ciência da Informação (BRAPCI), Web of Science and Scopus. There are 37 texts founded about the concept of hybridity in libraries: (Pinfield et al., 1998a), (Pinfield et al., 1998b), (Pinfield, 1998), (Oppenheim et al., 1999), (Leggate, 1999), (Guy, 2000), (De Marcas et al., 2000), (Mlekus, 2000), (Gambles, 2000), (Garrod, 2001), (Pinfield et al., 2001), (Breaks, 2002), (Dent et al., 2001), (Brophy, 2002), (Roberts, 2002), (Casserly, 2002), (Garcez et al., 2002), (Guy, 2003), (Kolloffel et al., 2003), (Hamilton, 2004), (Covi et al., 2004), (Pugh, 2004), (Pugh, 2005), (Carr, 2006), (Orera-Orera, 2007), (Miranda et al., 2007/2008), (Pinto et al., 2012), (Da Silva et al., 2017), (Da Silva et al., 2017) and (Da Silva et al., 2018). These articles will be analyzed from a Fairclough perspective. In a later approach, the authors intend to go personally to American hybrid libraries (to be established), to analyze their documentation and governance. A brief analysis of the production process showed that the concept of hybrid libraries is being developed in countries like England, Scotland, Wales, Brazil, United States, Denmark, Israel, Slovenia, Australia, India, Africa, Germany, Belgium, Spain and Colombia. All the authors analyzed reference sources from the United Kingdom, where, historically, the concept was born. Nowadays, the concept of hybrid libraries has been more discussed in countries where the libraries are becoming hybrid (such as developing countries). On the other hand, in countries where most of their libraries are hybrid, such as United States and European countries, the concept of hybrid libraries is discussed in order to understand how the convergence of technologies can contribute to the development of communities.

\section{Development and libraries}

Originally, the public sphere was perceived as a forum where the public opinion was formed. However, with the development of market strategies and the commercial character of mass media, it started to operate not only as the view of the civil society, as opposed to the State, but also considering the diverse public in society, being the public sphere when there is conflict of interests. In the public sphere, libraries are found as institutions which work with conflict of social interests through the treatment and provision of information to their public. The several types of libraries, including hybrid libraries, offer different types of development to society. For Da Silva et al. (2017), a hybrid library is a cultural equipment which integrates aspects of traditional libraries, as well as digital libraries.

In the face of that, it is understood that, in addition to the convergence of technologies, hybrid libraries must be a cultural space, adapting to the cultural characteristics of each community in which they are operating. According to Habermas (2000), society experiences three major axes of macro development: human, social and economic developments. In these types of development, there are underdevelopments, as it is the case of the technological development which, in the current context, faces the development of software, within the perspective of three macro developments. The institutionalized organizational development, as part of the economic and social development, opposes the professional development and, in the context of libraries, the development of collections, in addition to the human development. The cultural development is subsidized by the social development. Finally, all these developments are related to the idea of privacy versus accessibility of information, the political

Rafaela Carolina DA SILVA and Rosângela Formentini CALDAS (2020), Journal of Administrative Sciences and Technology, DOI: 10.5171/2020.558394 
development and the citizen participation in society.

The concept of development, since the Classic Philosophy with Socrates and Plato, brings the idea of the act power, that is, an action is powered by another action. After the Second World War, when the technological transformations occurred, development came to be seen from the perspective of a relative growth or potential possibilities to transform something or an action. Development is, therefore, situated in a specific space and time, capable of creating thoughts and political actions (Sachs, 1993). In general, development results from the economic growth and from the improvement in the quality of life, including issues of "poverty, unemployment, inequality, health conditions, nutrition, education and housing" (Vasconcellos et al., 1998). Thus, development needs to be understood as a complex process of economic, human and social changes, being more than growth, but a way to transform and satisfy the diverse needs of the human beings. In relation to the human development, it can be seen with the emphasis on the individual's historical-social process, because the human acquire knowledge and assets by interacting with other individuals in society (Furtado, 1974). With regard to the social development (Shera, 1977), traditionally, the sector includes education and health fields. When dealing with the economic development, Smith (2006) highlights that it turns to market laws, that is, to the creation of products and services that generate competitive advantages in economy. In the social sphere, this type of development is manifested in the distribution of revenues, considering its direct and indirect costs.

\section{Concept of hybrid libraries}

"The idea behind the label of hybrid libraries is not new and has been expressed by a number of writers who recognized early the need to join-up all the available types of information resources in order to come to a fully interlinked information environment" (Breaks, 2002). Therefore, the hybrid library is characterized by being a place that keeps its traditional and digital collection, using the Web as an additional mechanism of delivery, where users can access electronic information as well as relevant physical resources. To this end, the ways hybrid libraries operate aim at integrating a wide variety of traditional and new resources in the most uniform way possible, by means of print and digital meta-information. In this perspective, "The term 'hybrid library' is only a label to help our thinking of how libraries are developing" (Breaks, 2002).

According to Orera-Orera (2007), the hybrid library is "a mixed entity, where traditional documents, digital information and services offered in the facilities of the library coexist with other services offered online". Therefore, those libraries serve in person and remote users, becoming a sum of the real and virtual. Moreover, according to Orera-Orera (2007), some relevant aspects of those libraries are: 1 ) the new role of the librarian, whose importance is increasing due to the large amount of existing information and the need to treat it with defined quality criteria; and 2) the information management, which requires providing diversified training to cope with the diversity of professionals required in the different roles played by libraries.

Due to the arrival of digital medias, López Jiménez et al. (2005) understand hybrid libraries as models of libraries where the user, through a Web interface, pages or computer screens, can access digital 
resources. Therefore, "the title hybrid library is the most adequate in the transition from the traditional to the virtual, because it goes from the digital to the virtual without abandoning the print documents" (López Jiménez et al., 2005), thus keeping physical and virtual spaces in its structure. That being said, it is understood that in the hybrid library, the information on paper is handled in parallel to the electronic information, requiring the information professional, as a hybrid librarian, to know how to work with the information recorded in different media. Thus, Villa Barajas et al. (2005) claim that "the motivation behind the concept of hybrid libraries is the need to deal with diversity, which is an important issue when libraries advocate for a world where the information is globalized". Therefore, the information, on a large scale, is at stake. For that reason, Koltay (2008) considers that hybrid libraries are frequently identified as digital libraries. However, according to Ramírez Céspedes (2006), a hybrid library is "an intermediate environment between the traditional and the virtual library, where both formats coexist, and traditional services may exist as well as in the digital environment".

In a more social view, Da Silva et al. (2017) understand that, in addition to the convergence of technologies, the hybrid library must be "a cultural space that fosters dialogue, where individuals and technology interact, so that information kept in the library comes to life as it is useful to users and therefore used". Hence, the environment in these libraries is interactive and stimulating, capable of building a multicultural relationship of data, information and knowledge, with the concept of hybridity present in the promotion of information. In this context, like Vuren et al. (2009), Da Silva et al. (2017) state that hybrid libraries are only possible when the institutional structure and the professionals working at the institution work together, in order to build access and use the information wisely. Thus, the idea of hybrid libraries includes the need to better understand the users' requirements and behaviors and, therefore, the competence in information, which must be considered in the different departments in the library, so that professionals can act in order to recognize the potential of the hybrid library (Edwards et al., 1999). Hence, for the hybrid library environment to be able to serve all the users of the institution, cultural differences need to be recognized by these libraries' administration. This requires that such locations offer a variety of information sources, creating new ways of communication in order to facilitate the discussion about the information received among users. It is, therefore, a space of continuous learning, where employees and users need to acquire a variety of skills to deal with the information.

\section{Preliminary Results and Discussions}

The term 'hybrid libraries' originates from the combination of the concepts of traditional, electronic, digital and living libraries, from the prespective of the environments that meet to offer greater access to information and a better understanding of the librarian expertise in contemporary social contexts of innovation. The processes adopted by these libraries have attributes of languages used by each institution, with purposes that meet the informational needs of users in innovative operating environments.

The impact of the social development on hybrid libraries lies in the fact that, from the moment the individual becomes more important than the techniques and technologies of information processing for the development of their products and services, those institutions become characteristics of a new concept. Such concept focuses on a field of study where hybrid libraries are no longer understood

Rafaela Carolina DA SILVA and Rosângela Formentini CALDAS (2020), Journal of Administrative Sciences and Technology, DOI: 10.5171/2020.558394 
only by the convergence of technologies in the same environment, but by the use of Information and Communication in the process, meeting users' needs and desires.

In this scenario, the library is discussed as a social institution which values the understanding of human uncertainties, raising resources and procedures to ensure that these uncertainties are eliminated through the qualifications and participation of the individual in society. In this sense, the technologies, being always present in hybrid library tasks, are now characterized as auxiliaries in the library processes, whose main objective is the information access by users, so that they become autonomous individuals in the use of the information accessed. For this reason, hybrid libraries are potential agents for transforming their communities at intellectual and social levels because, in addition to being mediators, they are active entities in accessing education, information and knowledge. Therefore, the hybrid informational equipment must consist of professionals who aim to manage the knowledge existing in society. In order to do so, they need to understand how the library operates as an organization, as well as the relationships among the people in this organization. In this sense, it is assumed that the hybridity applied to libraries can improve the information management processes and, consequently, the management and organization of people. Hybridity, as a perspective of socio-cultural inclusion, assumes the social development as it directs the work of libraries towards the management of information based on the development of their communities.

It is noticed that in the hybrid library environment, there is a greater flexibility of products and services offered, since they originate from an organizational structure that proposed multiplicity of languages in the work of the institution, encompassing not only the convergence of printed and electronic technologies, but also studying the libraries' communities needs for taking decisions. Therefore, a hybrid library must be a cultural space that allows the promotion of dialogues based on the view that the information registered in site must come to life as it is used. Thus, it can be said that the concept of hybridity in libraries meets the most recent research in Information Science in the world context, involving paradigms that did not exist before.

When observing the historical construction of hybrid libraries, it is possible to understand that, when the concept was first considered, it focused on the implementation of digital technologies in the library scope. In this perspective, the aim was to understand how the library management should behave in relation to the acquisition of information and communication technologies, as well as the expenses, costs and benefits that these new technologies would bring to the library context, emphasizing the economic development for the technological development. Thus, it was necessary to study the costs of acquiring a new software and hardware, understanding the benefits and harms of this acquisition for both the institution and the public. The vast majority of studies on this subject, in the late 90 s and early 2000 s, are linked to the technological development undergone by traditional libraries and to the software development covering data interoperability and library development programs.

With the understanding of the best and most adequate software and hardware necessary for the library routine, in addition to the acquisition and installation of those in the library environment, these institutions faced a 
technological convergence. However, these technologies would be of no use without professionals trained for their proper use, according to the mission and vision of the organization. In this scenario, in the late 90s and early 2000s, studies on the professional development emerged within the human development aspect, that is, the ways in which it would be possible to enable information professionals to make better use/benefit of the language convergence provided by these locations.

Along with the professional development, there was an urgency to start the training of these professionals not only on their information needs, but also on their professional desires. Thus, the concept of hybrid libraries comprises the study of users and communities, in order to understand their contexts and develop products and services according to their demands. In the third stage, in the early 2000s, researches on hybrid libraries focused on the collection development, taking advantage of the great possibilities to access information (in the institution itself or other institutions) brought by electronic and digital technologies. In this view of data exchange, the analysis of the privacy versus accessibility issue was initiated, with the aim of offering a wide variety of information to the users without violating their physical and/or legal rights. There was a counterpart between the traditional and digital environments, from the point of view of institutionalized organizational developments (with purposes not only in the market, but also in the social character of their actions) and social developments, which has an impact on the human and economic developments.

In this perspective, the concept of hybrid libraries is seen, in the first instance, from the perspective of the social development, emphasizing its political and cultural aspects, since it expanded according to institutional (library) and cultural (employees and external community) policies, including an organization structure approach (internal environment) and the external contexts surrounding them (other institutions, public and private policies, among others). Thus, in the second instance, the institutionalized organizational development of these cultural equipment was emphasized, to the extent that organizational studies would range from initial approaches of understanding the concept of hybridity in libraries (technological and software development) to human, social, economic, collection, political, professional and cultural developments, that is, they would span the human, technological and financial resources of these organizations, institutionalized under the law in society. In this penultimate perspective, the focus of the processes of hybrid libraries was at the operational (library performance) and tactical (library management) levels, since it focused on short and mid-term planning, always highlighting the social development when dealing with users and employees of these organizations.

In the mid-2000s, the hybrid library started to stand out in the medium and long term management, encompassing the strategic, tactical and operational levels. In this context, the concept of hybrid libraries is essentially focused on the human and social developments, having an economic impact as it understands that the human resources are the most complex twithin organizations, as they are subjective beings and that, like technologies, they are constantly renewed. In this scenario, taking into account that, in order to work on the institutionalized organizational development of hybrid libraries, which generates information products and services that impact their economic development, it is necessary to understand their human and, consequently, social development, which are shown as the focus of these libraries. 


\section{Preliminary conclusions}

Hybrid organizations must understand that they are largely driven by the access to content in multiple sources, as well as by changes originated from users' needs, which affect the range of services provided by libraries. In this sense, the hybrid library operates in the cultural sphere when its communities operate in the work of the library. Technologies are characterized as tools that assist in the development of services offered by libraries, that is, in professional practices within libraries that aim to make users able to interpret the information they receive and, thus, generate and share knowledge in society, which allows a greater participation of these subjects as citizens, in the different contexts.. Thus, the epistemological discussion in the construction of a concept about hybrid libraries that can be applied to different locations in the world, according to their cultures, values and principles (and, for that reason, individuals from each location will internalize a concept according to their characteristics and beliefs) needs to take into account the impact of the use of technologies and the provision of services that promotes the social inclusion of communities in each hybrid environment.

Therefore, there is the need for different discussions about fundamental themes in order to have a conceptualization of an object of study, due to the multiplicity of conceptions brought by various subjects. From this point of view, and understanding that the concept of hybrid libraries results in several possibilities, conceptually standardizing the term is feasible for a systemic context of that library, in order to achieve a semantic interoperability in the exchange of information.

The study showed that, currently, the main type of development in the hybrid library environment is the social development, since, although the technological development is part of the constitution of the concept, these libraries make use of technologies as strategic tools in order to achieve the social development. Social development is understood as educational activities performed by hybrid libraries in order to socially include their users. In addition, it is possible to find political, professional, software, organizational, economic, collection, accessibility and cultural developments in the hybrid library environment.

For a more didactic reading, the macro developments investigated in this study for the general context of societies are: human development, social and economic development, which together form the institutionalized organizational development, when it comes to the context of an institution. The underdevelopments provided by hybrid libraries are: technological development, political development, professional development, software development, collection development, privacy versus accessibility development and cultural development. Thus, by encompassing the aspects that constitute the human and social development, it is possible to enter the institutionalized organizational development of hybrid libraries, capable of providing valuable products and services for the society (assets). These are the means a hybrid library must use

so that its products and services can meet the informational needs of its users, making them autonomous researchers and able to generate new knowledge. It is not, therefore, about waiting for users to come looking for library services, but about delivering the information to them through the development of educational activities and creating an attractive environment, with convergent technologies and services for all the 
public of the institution (regardless of race, age, gender, etc.), when working with the users' informational and educational desires. It is a complex way of accomplishing the macro developments mentioned in this study, along with their underdevelopments.

\section{Acknowledgment}

The authors thank the Fundação de Amparo à Pesquisa do Estado de São Paulo (FAPESP), process number 2018/03999-2, for funding this research.

\section{References}

- Arendt, H. (1983) A condição humana, Forense Universitária, Rio de Janeiro.

- Breaks, M. (2002), 'Building the hybrid library: a review of UK activities', Learnerd Publishing 15, 99107.

- Brophy, P. (2002), 'The hybrid library', Bulletin des Bibliotheques de France 47, 14-20. [Online], [Retrieved November 22, 2018], https://search.proquest.com/docvie $\mathrm{w} / 57504628$ ? accountid=8112.

- Carr, R. (2006), 'What users want: an academic "hybrid" library perspective', ARIADNE (46). [Online], [Retrieved March 13, 2019], https://search.proquest.com/docvie $\mathrm{w} / 57654523$ ?accountid $=8112$.

- Casserly, M. F. (2002), 'Developing a concept of collection for the digital age', Portal: Libraries and the Academy 2, 577-587. [Online], [Retrieved November 22, 2018], https://search.proquest.com/docvie $\mathrm{w} / 57605955$ ?accountid=8112.

- Covi, L. M. and Cragin, M. H. (2004), 'Reconfiguring control in library collection development: a conceptual framework for assessing the shift toward electronic collections', Journal of the American Society for Information Science and Technology 55, 312-325. [Online], [Retrieved
November 22, 2018], https://search.proquest.com/docvie $\mathrm{w} / 57594070$ ?accountid $=8112$.

- Da Silva, R. C. (2017) Gestão de bibliotecas públicas no contexto híbrido: um estudo comparativo de bibliotecas híbridas no âmbito nacional e internacional em prol do desenvolvimento de comunidades. University of Sao Paulo, Marilia.

- Da Silva, R. C. and Caldas, R. F. (2017), 'Las bibliotecas públicas híbridas en el contexto brasileño', Palabra Clave 6 (2).

- Da Silva, R. C. and Jorente, M. J. V. and Caldas, R. F. (2017), 'Integração da competência em informação no contexto das bibliotecas vivas', Revista Ibero-Americana de Ciência da Informação 10 (2). [Online], [Retrieved October 13, 2019], http://www.brapci.inf.br/v/a/30301

- Da Silva, R. C. and Ottonicar, S. L. C. and Caldas, R. F. and De Castro Filho, C. M. (2018), 'A competência em informação e o comportamento informacional dos usuários de bibliotecas híbridas: um estudo comparativo no Brasil e na Escócia', Informação \& Informação 23, 398423. . [Online], [Retrieved January 20, 2020],

http://www.uel.br/revistas/uel/inde x.php/informacao/article/view/3090 6.

- De Marcas, J. and Branse, Y. and Golan, Y. and Igra, I. (2000), 'Hybrid library development at the university of Haifa library', Library Review 49, 165-172. [Online], [Retrieved January 20 , 2020], https://search.proquest.com/docvie $\mathrm{w} / 57513740$ ? accountid $=8112$.

- Dent, V. and Hall, W. and Harris, S. and Hey, J. and Martinez, K. (2001), 'Agent technology concepts in a heterogeneous distributed searching environment', Vine 123, 55-63. [Online], [Retrieved January 11, 2020], 
https://search.proquest.com/docvie $\mathrm{w} / 57511800$ ?accountid $=8112$.

- Edwards, C. and Wynne, P. (1999), 'The HyLife experience: a checklist of challenges facing the development of hybrid library services', New Review of Information and Library Research 5, 145-159.

- Foucault, M. (1971) Sobre a arqueologia das ciências: resposta ao círculo epistemológico, Vozes, Petrópolis.

- Gambles, A. (2000), 'The development and launch of the HeadLine personal information environment', Information Technology and Libraries 19, 199-205. [Online], [Retrieved January 11, 2020],

https://search.proquest.com/docvie $\mathrm{w} / 57498100$ ?accountid=8112.

- Garcez, E. M. S. and Rados, G. J. V. (2002), 'Biblioteca híbrida: um novo enfoque no suporte à educação a distância', Ciência da Informação 31(2). [Online], [Retrieved January 15 , 2020], http://www.scielo.br/scielo.php?pid =S010019652002000200005\&script =sci_abstract $\&$ tlng $=$ pt.

- Garrod, P. (2001), 'Staff training and end user training issues within the hybrid library', Library Management 22, 30-36. [Online], [Retrieved February 13, 2020], https://search.proquest.com/docvie $\mathrm{w} / 57467259$ ? accountid=8112.

- Guy, R. F. (2000), 'Developing the hybrid library: progress to date in the national library of Scotland', Electronic Library 18, 40-50. [Online], [Retrieved September 20, 2020], https://search.proquest.com/docvie $\mathrm{w} / 57500478$ ?accountid $=8112$.

- Hamilton, V. (2004), 'Sustainability for digital libraries', Library Review 53, 392-395. [Online], [Retrieved March 01, 2020], https://search.proquest.com/docvie $\mathrm{w} / 57585911$ ?accountid $=8112$.
- Kolloffel, J. and Kaandorp, A. (2003), 'Developing a cost/benefit financial model for hybrid libraries', Serials 16, 41-49. [Online], [Retrieved May 11, 2020], https://search.proquest.com/docvie $\mathrm{w} / 57574174$ ? accountid=8112.

- Koltay, T. (2008), 'Digital library issues in Hungarian LIS curricula: examples from three libraries schools', Library Review 57, 430-441.

- Leggate, P. (1999), 'User access to the hybrid library', IATUL (8). [Online], [Retrieved January 11, 2020], https://search.proquest.com/docvie $\mathrm{w} / 57562411$ ? accountid $=8112$.

- López Jiménez, C. and Alfonso Sánchez, I. R. (2005), 'Las bibliotecas a comienzo del siglo XXI'. ACIMED 13(6).

- Miranda, A. and Leite, C.; Suaiden, E. (2007), 'A biblioteca híbrida na estratégia da inclusão digital na Biblioteca Nacional de Brasília', Inclusão Social 3, 17-23. [Online], [Retrieved April 20, 2019], http://revista.ibict.br/inclusao/articl e/view/1615/1821.

- Mlekus, H. P. (2000), 'Evaluation of library collections and the hybrid library', Knjiznica 44, 25-33. [Online], [Retrieved January 19, 2020], https://search.proquest.com/docvie $\mathrm{w} / 57519168$ ? accountid $=8112$.

- Oppenheim, C. and Smithson, D. (1999), 'What is the hybrid library?', Journal of Information Science 25, 97112. [Online], [Retrieved April 18, 2019], https://www.researchgate.net/publi cation/248422708_What_is_the_hybr id_library.

- Orera-Orera, L. (2007), 'La biblioteca universitaria ante el nuevo modelo social y educativo', El Profesional de la Información 16, 329-337.

- Pinfield, S. (1998), 'Managing the hybrid library', SCONUL Newsletter 41-44. [Online], [Retrieved January 20,

2020], 
https://search.proquest.com/docvie $\mathrm{w} / 57445987$ ? accountid $=8112$.

- Pinfield, S. and Dempsey, L. (2001), "The distributed national electronic resource (DNER) and the hybrid library', Ariadne (26). [Online], [Retrieved February 20, 2020], https://search.proquest.com/docvie $\mathrm{w} / 57469740$ ?accountid $=8112$.

- Pinfield, S. and Eaton, J. and Edwards, C. and Russell, R. and Wissenburg, A. and Wynne, P. (1998a), 'Realising the hybrid library', New Review of Information Networking 4, 3-21. [Online], [Retrieved March 13, 2019], https://search.proquest.com/docvie $\mathrm{w} / 57469110$ ? accountid=8112.

- Pinfield, S. and Mckenna, B. (1998b), 'The Builder Project', Electronic Library 16, 305-307. [Online], [Retrieved January 20, 2020], https://search.proquest.com/docvie $\mathrm{w} / 57431459$ ?accountid=8112.

- Pinto, M. and Uribe Tirado, A. (2012), 'Hybrid public libraries in the context of information literacy', Documentación Científica 35, 136168. [Online], [Retrieved January 20, 2020], https://search.proquest.com/docvie $\mathrm{w} / 1496969056$ ?accountid=8112.
- Pugh, L. (2004), 'The management of hybrid libraries', New Review of Information Networking 10, 71-83. [Online], [Retrieved March 13, 2019], https://search.proquest.com/docvie $\mathrm{w} / 57589374$ ? accountid $=8112$.

- Pugh, L. (2005), 'The management of hybrid libraries', Library and Information Research News 29, 13-31. [Online], [Retrieved March 13, 2019], https://search.proquest.com/docvie $\mathrm{w} / 57610040$ ?accountid=8112.

- Ramírez Céspedes, Z. (2006), 'Criterios e indicadores para evaluar las bibliotecas digitales', ACIMED 14, 1-13.

- Roberts, S. (2002), 'Access versus ownership in academic libraries: some reflections from the literature', Education Libraries Journal 45, 5-11. [Online], [Retrieved March 13, 2019], https://search.proquest.com/docvie $\mathrm{w} / 57542251$ ?accountid=8112.

- Villa Barajas, H. and Alfonso Sánchez, I. R. (2005), 'Biblioteca híbrida: el bibliotecario en medio del tránsito de lo tradicional a lo moderno', $A C I M E D$ 13(2). 